\title{
Essentials of a University Library Building-II
}

\author{
Dr. Raney is director of libraries, Uni- \\ versity of Chicago.
}

$\mathrm{W}$ HATEVER significance may attach to this statement derives from experience at two peculiar institutions. The experience was marked by the presentation of building plans that received unanimous faculty approval and were delivered in a blue print of essentials to the administration before the appointment of an architect. He was thus saved months of threshing around to learn his clients' problem and could sit down at once to the evolution of graceful expression.

The two peculiar institutions were the Johns Hopkins University and the University of Chicago. The peculiarity lay in their having been born universities, without antecedent college stage. Universities for discovery, colleges for disclosure. To this day research remains the dominant function both at Homewood and on the Midway for all the press has to say about it.

These great faculties proved to be of one mind as to what constitutes effectiveness of arrangement in pioneering operations. The approved plants would to the eyes of a visitor have not the slightest external resemblance, but the worker at his desk would find essentially the same conditions in the two cases, and the men of ' 76 and ' 92 saw the essentials just as clearly as they of 1916 and ' 36 . Gilman Hall is no truer an embodiment of that ideal than McCoy Hall before it. You never find the graduates from Howard Street bemoaning the arrangements of their day. They outgrew the site, not the idea. If the denizens of Harper Memorial are not as happy the reason is that they had no part in its planning. But ask the workers in Eckhart Hall what they think of that collusion between faculty and librarian.

There is another peculiarity about the Baltimore situation. Homewood has no building called the library. The librarian and his technical staff have quarters in Gilman Hall but that does not make it the library, though where sits MacGregor is said to be the head of the table. The president used to be ensconced there, too, but Administration was not chiseled over the door. In fact the preliminary designation of this structure was Academic Building. It is the seat of the humanities and the social sciences. There the faculties abide and direct their work. The library is the heart of the establishment, but no more nor less so than Remsen Hall where the chemists cluster about their books. These hearts, like any other, would be of no use outside the body in which they beat, despite Dr. Carrel's success with a chicken's.

\section{Secret of Faculty Contentment}

What's the secret of faculty contentment, the primordial cell of a true university library building? For answer turn back to a room in old $\mathrm{McC}$ oy Hall, long 
since in ashes. Here sat the professor of political science at his desk in a window corner. The walls were filled with books on the subject. Out on the floor stood a long table, a lectern at its head. Students lined the table or fingered at the open shelves. At appointed seasons the figure in the corner would approach the lectern and speak for an hour or sit beside it in a free-for-all. The rest of the time they sat in silence together or moved quietly, working at a common store-the world's cloud of witnesses, past and present, tiered round the room, thanks to the miracle of books, while eager questioners on the floor under a vocal leader sought the further truth that would set men still more free. A primitive scene, but good enough for Woodrow Wilson and his classic dissertation on Congressional Government. That was a university of political science-that and that only.

For picture, then, set down a square so accoutred as the genesis of a university, including its library. But the room will be outgrown by increase of books, students and guiding force. It splits, after the manner of all growing cells, as it expands. Then set a vertical line dividing the square into halves. Put books and students in one rectangle. Divide the other half into several smaller rectangles by horizontal lines, thus creating a series of faculty studies terminating in a corner seminar adjoining the library. For accessibility tramp out the vertical line to a path we moderns call a corridor.

This pattern was repeated for other subjects, and each science was laid in the appropriate laboratory. Left-over materials were gathered in a separate store common to all; i.e., general reference works and periodicals, proceedings of learned organizations nonsectionalized in publica- tion, etc. The correlation of these patterns makes a university, and the Johns Hopkins group knew it from the start.

\section{A Dual Arrangement}

All that I did at Homewood in the nonlaboratory subjects was to pile up these patterns so that the library rectangles should be in a vertical line, thus securing the compactness and economy of stack construction but in two piles instead of one, with light court between. It was not architectural considerations that led to this dual arrangement, though, to be sure, tall buildings are not in the Colonial tradition. The reason was quite another. It was to secure double correlation of subjects. Thus the two columns read from the ground up as follows: classics, romance languages, history, on the one side; philosophy, English and German, political economy and political science; on the other. Horizontally, classics and philosophy get paired, the modern languages grouped, and the social sciences assembled.

But whatever the correlations and however much else in the plan, Gilman Hall remains essentially the multiplication of one cell and that always contained the master, kindred youth, and all like spirits of the dead and distant, linked in the great emprise of pushing back the boundaries of Old Night.

Men of the same order delved at Chicago but there had been commitments to influence the pattern's form without altering its intent. Chicago is bigger but more compact. Closely knit with the basic disciplines were the six professional groups: business, divinity, law, library, medicine and social service administration. And Chicago had set the college distinctly out.

These past commitments led to a decision of commanding importance; viz., to 
break the planning into three parts: college, natural sciences (including the medical application) and the combined humanities and social sciences (including their five professional applications).

\section{Arrangement Would Obey Curriculum}

As for the college, put its books in the college building wherever erected. A separate site across the Midway, with dormitories flanking, is much favored. The arrangement would obey the curriculum. Its outlines are fairly clear.

College at Chicago means for the time being junior college and it has its own dean, faculty and budget. Combination, however, with the last two years of high school to form a new four-year unit of general education, leading probably to a degree, has been given theoretical approval. The course consists of four surveys each running through a year-biological sciences, physical sciences, social sciences, humanities-plus two "sequences," which give a first expansion to two chosen subjects, also running each a year. The surveys would be implemented in a sizable reading room with adjacent stacks for reserves and browsing. The sequences would be supported in as many conference rooms as possible, each with a small stock of appropriate books.

I spoke of a planted discovery. Chicago is strongly committed to very definite planting. Syllabi, annually revised, name the essential and optional reading deemed sufficient to set the habit of discovery, for this, not the accumulation of facts, is the end of education. The college library, therefore, would not be large or growing, fresh texts replacing the outdated, and a core of classics unchanging. The librarian would not be a technician, but a guide, philosopher, friend-a professor of books.
As for the natural sciences, erect a science capitol somewhere along the line tying the old laboratory group and medicine. Put in it all the biology, medicine, psychology and (physical) anthropology, plus the overflow (that is, generally, the older material) from cliemistry and the rest, together with provision for a department of the history of science. Thus while a book was needed in experiment it would stay in the laboratory library. When it became historical it would pass to the capitol. The site for this building is chosen and planning authorized.

As for the humanities and social sciences, there are serious commitments that have rendered effective planning exceptionally difficult, but a way has been found to united acceptability. The commitments consist of existing buildings, for art, classics, modern languages, social sciences, business, law, divinity, orientalia-all near by - and education three blocks away. All these have libraries except the social science building.

The accepted plan calls for the erection of a tower behind Harper Memorial Library that will serve for its two divisions the same general purpose as the science capitol does for its two. Harper tied to the tower at three levels would have a reference reading room, an administration floor and space for the Graduate Library School. Put in the tower all of social science and the overflow of the rest. The tower has a stack core flanked on each side by reading rooms, with control in front and faculty studies in the rear. Kindred subjects would be paired at four levels as at Homewood-history with (social) anthropology and philosophy, economics with business, sociology with social service, political science with rare book and other special collections plus underground touch 
with law-books thus between those who would jointly use them. The difference from Johns Hopkins would be in the conduct of seminars in the existent buildings, but, as in Baltimore, the faculty, students

\section{Discussion}

Ralph E. Ellsworth, director of libraries, University of Colorado, discussed the papers by Messrs. Walter and Raney, commenting:

DR. RANEY's lively presentation of the philosophy behind the building program of Johns Hopkins and Chicago succeeds in presenting a logical program based pretty much on the pattern of the political science room in old McCoy Hall, adapted, of course, to recent educational trends.

Mr. Walter's paper on library construction synthesizes in an admirable manner most of the theories and facts of library construction that have been generally accepted on an empirical basis by the profession. If one were to read all the literature on library construction he would come out with a picture similar to that drawn by $\mathrm{Mr}$. Walter. Since this picture is the result of a cumulation of wisdom and practical experience over a long period of time, it embodies all the advantages and disadvantages of empirical knowledge. Yet because this picture is composed in this manner, we as a profession ought to be wary of its validity. We ought to test in the most careful manner the assumptions underlying it. During the last two years while I have been engaged in planning a university library building, I have been appalled and distressed, time and time again, by the fact that there seemed to be no solid foundation for most of the principles and practices we are following. To illustrate my contention I should like and books of a subject would abide together.

Gilman and Harper, both stemming from Yale, agreed on that cell, and they are everlastingly right.

to examine one generalization to which lip service is frequently given, and to demonstrate that we cannot plan good library buildings until we prove or disprove the assumptions underlying our practices.

First, we say that the library should be functional, that it should serve the university of which it is a part. That statement is based on the assumption that if books present ideas and concepts which the university is trying to pass on to the students, then the administration of books will be determined by the educational philosophy of the university.

What then are the educational philosophies which determine what we are supposed to do? The American university today is wracked by conflicting ideologies. The university once functioned on the assumption that it was first to connect the capable youth with the stream of man's thoughts and accomplishments, and second to prepare a youth for leadership in the various professions. During the last fifty years we have seen intellectualism crowded to the wall by utilitarianism, first by the multiplication of professional schools and courses which became substitutes for intellectualism, and then by the introduction of preprofessionalism in the arts college as a means of preparing an increasing enrolment for positions and as a result of the inability of the teachers of the humanities to avoid professionalizing that which should not be professionalized. Lately, we are witnessing a reversal of this policy due, probably, to the fact that the previous policy has failed to produce citi- 
zens who can solve the basic problems of our common social life. American society is making many contradictory and confusing demands on the university today. Yet amongst these one stands clearly above the others-society is demanding that the university turn out graduates who understand the background of the present day, who speak the same languages, and who are capable of thinking accurately on problems of social importance.

Today we see the arts college trying to throw off the smothering cloak of preprofessionalism and trying to compose a curriculum that will possess unity and coherence as well as utility. We see a tendency for the university to desire to admit only those students who are capable of mental work of a higher caliber. This desire is being thwarted because the university has no alternative program for the students of lesser ability. Whether the university will in the future embrace the vocational and professional schools as an inherent part of its organism, hold them at a distance in some kind of affiliation, or cast them out altogether remains to be seen. Thus far the advocates of intellectualism have been unable to break the strangle hold on preprofessionalism as practiced by some departments, except in the lower division. Most of us are acquainted, I am sure, with the general college programs of Chicago, Columbia, Colgate, etc. You will note one thing about all of these, they require all students to read a common group of books. This material is not particularly extensive, but it is carefully selected to accomplish a specific end.

\section{Trying to Break Down Separatism}

Today we see educators trying to break down, in various ways, the separatism which has reigned so long: first, by adopting a divisional rather than a departmental administrative mechanism; second, by means of an honors or reading program which cuts across traditional departmental lines; third, by the adoption of a major plan which is much broader than its predecessor; and fourth, in a few institutions which take their research program seriously, the instructors take upper classmen out on the firing line and give them an opportunity to help create knowledge as well as absorb it. Whenever the latter is done in a wholehearted and vigorous manner separatism is automatically limited.

The conflict I have described is not the only one now in vogue in the university, but it is probably the most important one and it is one that has direct implications for the library. I shall mention a few of the other problems.

First, the traditional reading room and stack room combination, as we know it, appears to be outmoded. Reading rooms must combine seating space along with a shelving capacity large enough to enable the faculty to place in an instructional situation those books which are directly pertinent to the curriculum. The stack room will give up its instructional function in favor of pure storage for all except the advanced researcher.

To do this we shall have to substitute the idea of several divisional reading rooms for a single room. Then we shall have to plan these rooms so that they will house the basic literature of each field and so that each room will contain all of the fields which logically belong together. We shall have to fill the rooms with alcove wall cases and with rows of shelves spaced throughout the room so as to break it up into relatively small units. The effect of having small "bookish" units instead of a 


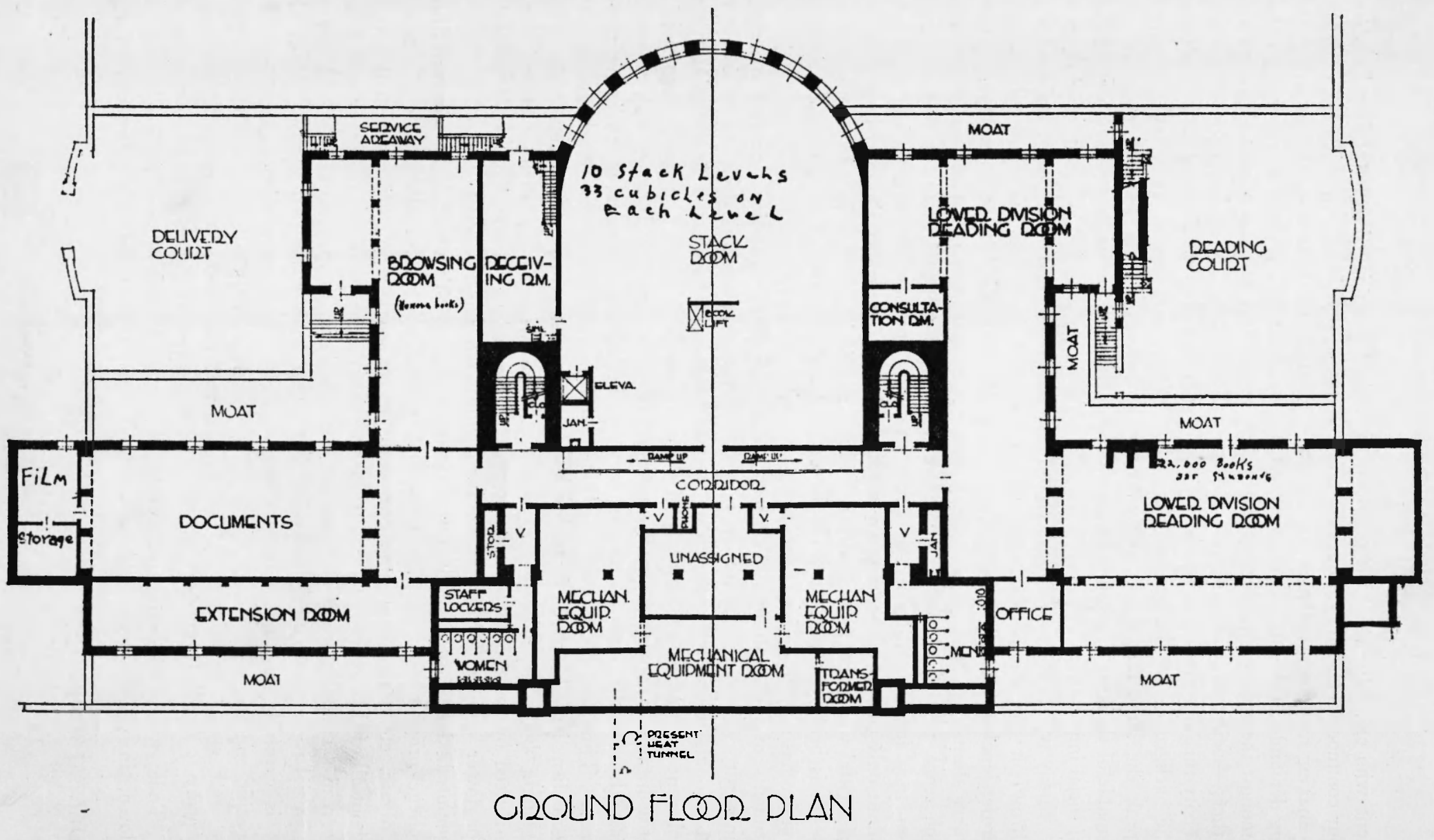

University of Colorado Library Plans 


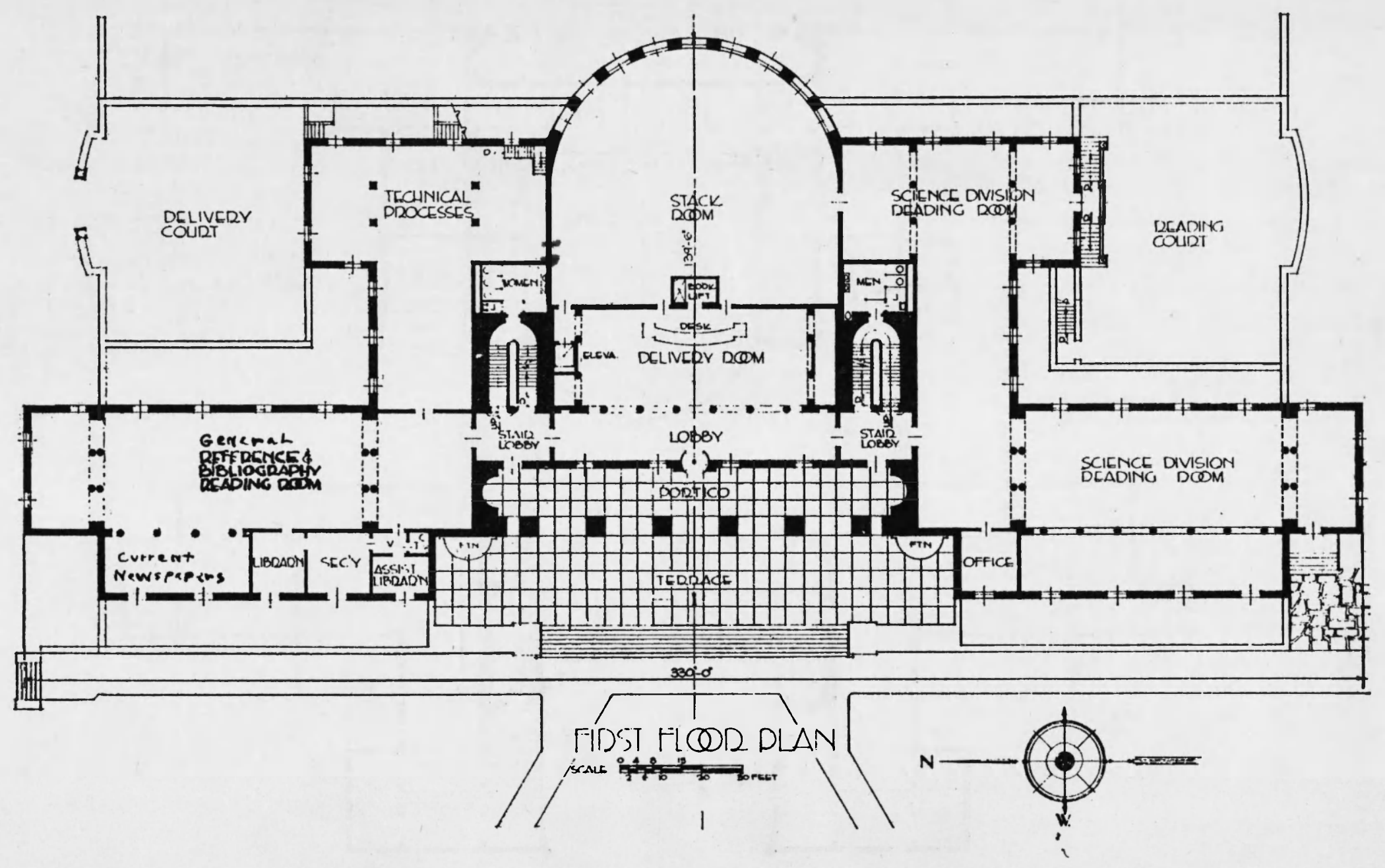



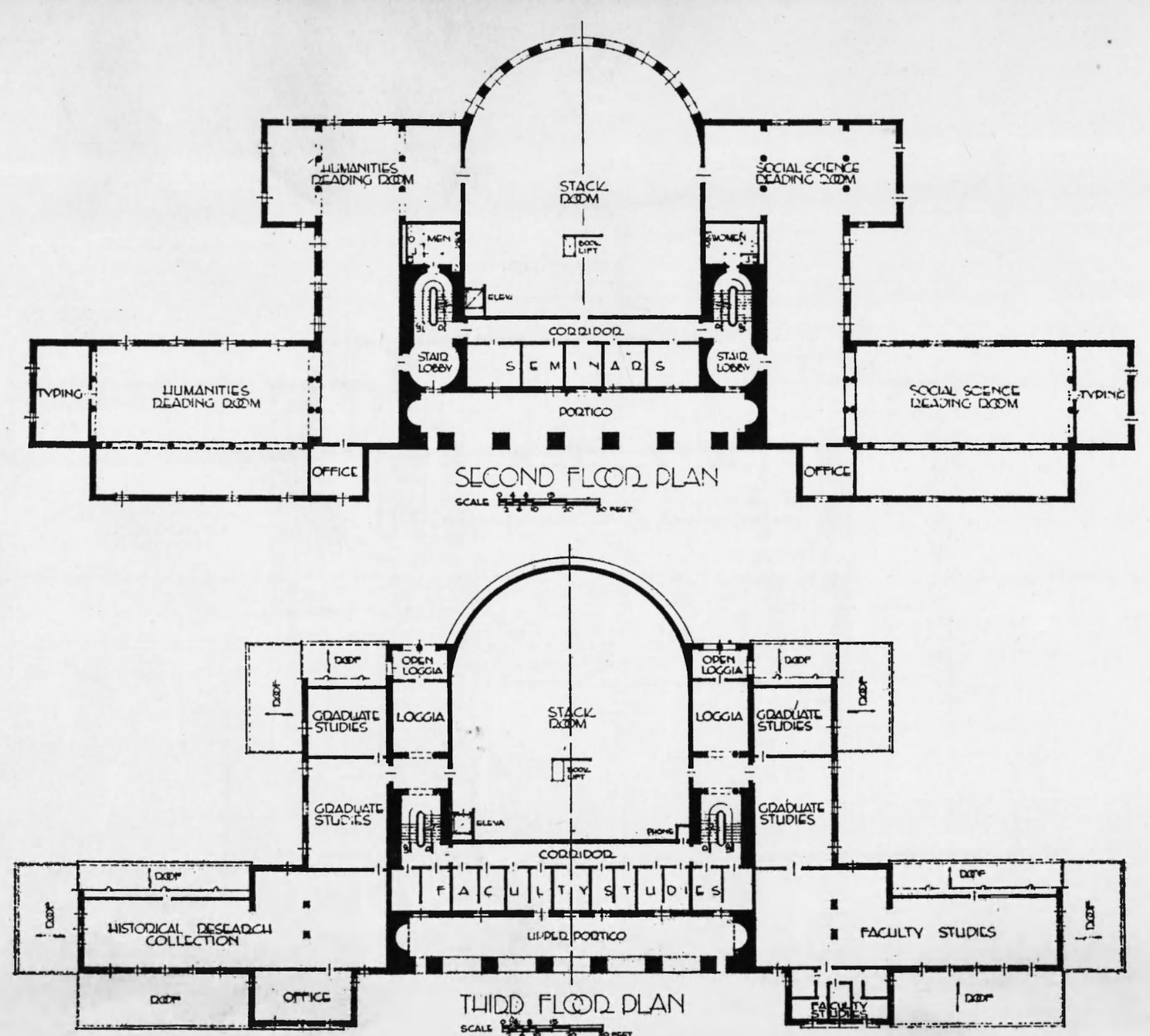


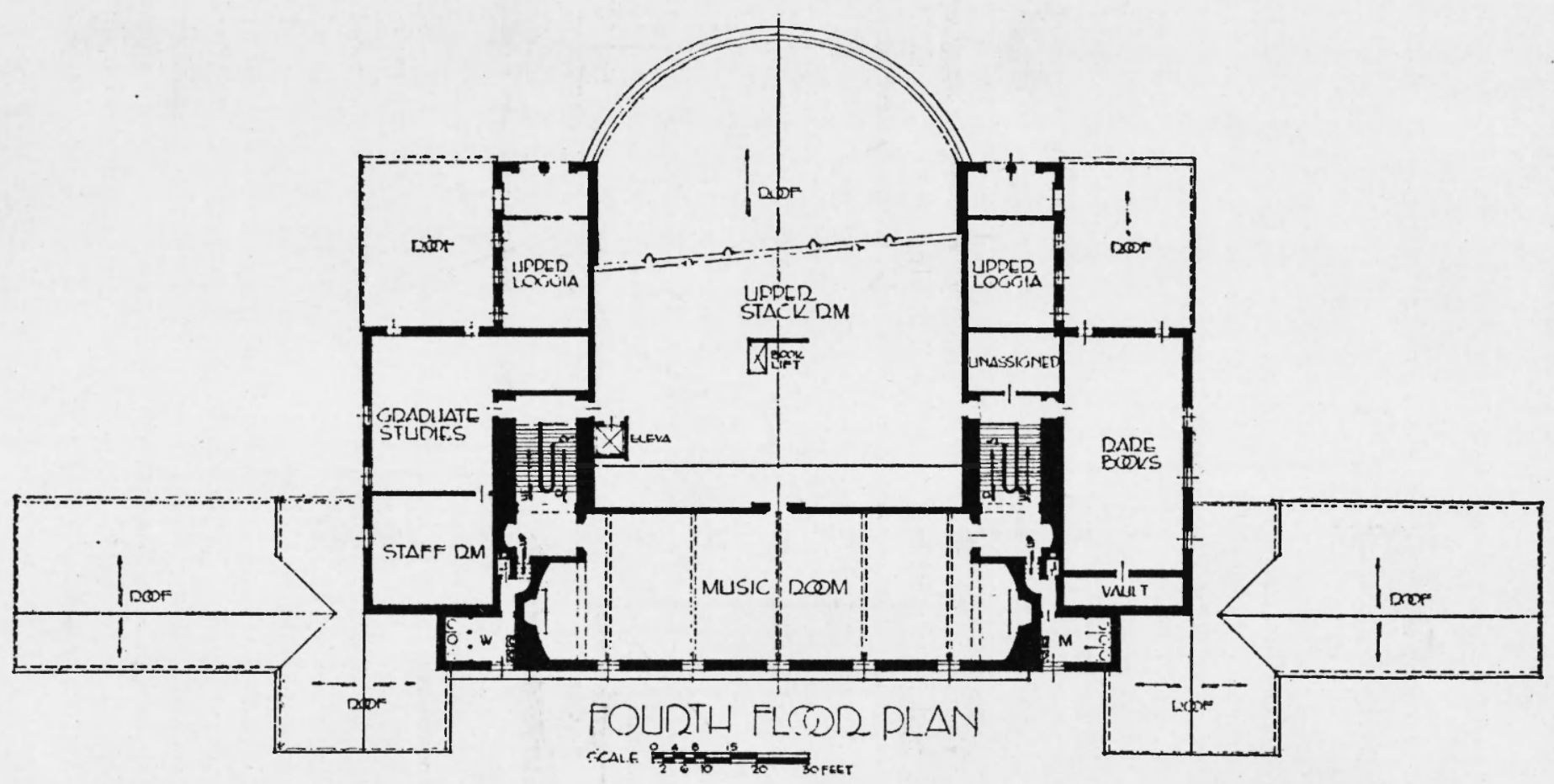


spacious reading room will be to make reading pleasant and interesting. All books will have to be on open shelves, which means that the exits will have to be closely guarded.

A word or two more about the contents of the collection is necessary. It is to be an instructional collection-that is, it is to contain all of the material which the faculty judge to be directly pertinent to their courses or fields. It will have to be closely selected. Irrelevant materials go into the stacks, which of course must be adjacent to the divisional reading rooms.

Second, under the traditional library plan it is difficult to make use of subject matter specialist librarians without burdening them with clerical tasks. The divisional librarians ought to be subject specialists as well as technicians, because they will have little clerical work to do and they can devote their energies to interpreting books and to advanced bibliographic research.

Third, this plan may cause the general reference librarian's work, as we know it, to disappear, or to change radically in nature. It would seem logical to keep the specialized reference tools in the divisional rooms along with the specialized journals. That will leave the reference librarian with a collection of general reference books and general periodicals. If all books in the divisional rooms are charged from and returned to the rooms, then the use of the main charging desk should diminish almost to the vanishing point. If that is true, then why not combine that work with the reference librarian's duties and develop her as a kind of roving bibliographic librarian? She can serve to hold together all the divisional reading rooms and help keep their service unified.

Fourth, everyone assumes that the re- serve rooms must always be with us, and yet no one seems to ask why we have such rooms. One reason must be that the present combination of "reading-room-charging-desk-stack-room" is not adapted to modern instructional methods and that there had to be some efficient method of isolating the material needed for the various courses. The reserve system is efficient, all right, but it is entirely noneducational and noninstructional.

It would seem logical to shelve the socalled reserve books with the other books in the divisional rooms, all in one single call number order. It might work out that the presence of so many books in an open shelf situation would eliminate the necessity of placing so many books on reserve. Incidentally, it should be easy under this system to have four or five different categories of reserve books, some used indefinitely within the rooms, some charged out for one, two, or three days. There need be no limit since each book can be marked.

Fifth, I mentioned previously that the advocates of intellectualism or unity in higher education had had difficulty in pushing preprofessionalism out of the upper division, but that general college curricula for the lower division were fairly common. Whenever such curricula exist it would seem logical to have a separate divisional room where all the material for the lower divisional courses would be kept. This could be of a semi-permanent nature and would consist of those books which the university expects all freshmen and sophomores to read. If the curriculum has unity, the number of such titles would not need to be large, since a student can read only a few hundred books in two years.

(Continued on page 96) 
Part one of Mr. Downs' Guide deals with general classes, such as general reference materials, bibliography, library science, dissertations, documents, manuscripts, newspapers, general periodicals and society publications, directories, illustrations and ephemerae. Part two deals with special subjects, which Mr. Downs divides into five large groups-the humanities, the social sciences, science, technology, and special collections.

To give you some idea of the standard adopted, I have used the term good only when 50 per cent or more of the titles listed in the Guide are held in the province.

On the whole the general classes of part one are moderately good, if it is understood that the greatest emphasis for manuscripts, directories, newspapers and documents is on Canadian material.
The reference resources in the humanities are only fair. It must be admitted that the province is incomparably stronger in English than in any other language.

In the social sciences, the holdings are also only fair, although international relations, education and biography might be described as very good. Anthropology is weak, as is history, except in teaching fields.

The field of science is probably the best, although pharmacy and dentistry are conspicuous by their absence. In the province we have, for example, twelve of the thirteen serials listed for geology, four of six for astronomy, eight of nine for physics, fourteen of nineteen for chemistry and ten of twelve in medicine. Similarly for large sets, we have two of three in physics and three of five in chemistry.

The field of technology is well represented in engineering and agriculture.

\section{Essentials of a University Library Building}

\section{(Continued from page 56)}

There would be certain advantages in having a librarian who was more of an instructor than a librarian to direct the program of the lower divisional room. She could see to it that each beginning student learned how to use bibliographic tools and she could work with each one individually.

Sixth, the administration of such a system may seem complex at first, but actually it is much simpler than the one now in vogue. It has the further advantage of making possible the separation of professional from clerical duties. It may be somewhat more expensive than the present one, but if it accomplishes what it at- tempts to do, no one will grumble about the cost.

The purpose of this discussion was to demonstrate that university library planning appears to have fallen into a rut and that a fresh critical examination of the fundamental assumptions is much to be desired. A complete analysis of the suggestions proposed was not intended. Those of you who are interested can watch the success of this experiment at the University of Colorado where our new library building is embodying most of the ideas mentioned in this paper. 